\title{
Freedom as the Antithesis of Commitment in Jean-Paul Sartre's The Flies (Les Mouches)
}

\author{
Wafaa A. Mostafa Hussein \\ Professor of English Literature \\ College of Arts \\ Imam Abdulrahman Bin Faisal University
}

Doi:10.19044/1lc.v8no2a1

URL:http://dx.doi.org/10.19044/1lc.v8no2a1

Submitted: 06 March 2021

Copyright 2021 Author(s)

Accepted: 07 April 2021

Under Creative Commons BY-NC-ND

Published: 30 June 2021

4.0 OPEN ACCESS

\begin{abstract}
In the mid of the twentieth century, French Existentialism was a predominant doctrine that significantly enriched and influenced the literary scene in Europe during the Post-War area. Jean-Paul Sartre (1905-1980), the founder of Existentialism, is both a professional philosopher and a talented man of letters whose literary achievements represent a declarative embodiment of his Existentialist philosophy. In his 1943 drama, The Flies (Les Mouches), Sartre puts the Greek myth into a drastically innovative structure, where contemporary issues and values are presented through classical outlines. The current study aims to present a critical analysis of Sartre's depiction of the Electra/Orestes myth in The Flies through demonstrating how Greek mythology becomes an essential substructure of the play's Existentialistic framework, on the one hand, and questioning the credibility of the Sartrean concept of freedom and commitment, as illustrated in the play, on the other hand. The study utilizes the Existentialist philosophy as a theoretical framework in order to elucidate that the Sartrean conception of freedom and commitment is paradoxically antithetical. The research investigates how Orestes has been theoretically free and the extent to which he strives, throughout the drama, to transform this abstract freedom into a concrete experience by committing himself to a specific action: murdering Aegisthus and Clytemnestra. However, as the study proves, this Existentialist freedom becomes an illusion in the sense that Orestes' commitment to the Argives makes him a captive of society; by choosing commitment, he dismisses his freedom. The researcher has chosen "Freedom" and "Commitment" as the main topic of the present study in order to expose Sartre's existentialistic awareness of modern human beings' dilemma under the influence of all forms of aggression and highlight the discrepancy between theoretical philosophy and real-life experiences. The study adopts an interdisciplinary analytical approach where myth, philosophy, and drama are dovetailed and fused in order to expand the scope of the analysis.
\end{abstract}

Keywords: The Flies, Myth, Existentialism, Free Will, Commitment, Freedom, Guilt, Responsibility. 
Greek mythology, the traditionally received narrative that elaborates the essential elements, symbols, and themes of myth itself, provides an infinite source for artistic inspiration. Modern dramatists give Greek mythology a unique position in their literary achievements because myth allows the playwrights to create a meaningful theatrical world and communicate their distinctive artistic visions. It also bestows tremendous freedom of expression and facilitates presenting the current conditions in the light of historical and universal human experiences. As far as the conception and the meaning of myth are concerned, no generally agreed-upon definition would apply to all the instances of myth in creative works. It is difficult to establish a unitary definition of myth because it is both elusive and volatile. In Classical Greek culture, myth represents a "true story embodying cultural models and is the means by which a fundamental message is handed on from generation to generation." (Aspleyet al., 1982, p. 2) In such a civilization, myth is:a direct expression of its subject matter; it is not an explanation in satisfaction of a scientific interest, but a narrative resurrection of a primeval reality told in satisfaction of deep, religious wants, moral cravings, social submission, assertion, even practical requirements. Myth fulfills in primitive culture an indispensable function; it expresses, enhances, and codifies beliefs; it safeguards morality; it vouches for the efficiency of rituals and contains practical rules for the guidance of man. (Malinowski, 1971, p. 19)

Therefore, myth represents a fundamentally energetic force and a vital constituent of human civilization, even though it has lost all connection with religious faith nowadays. It performs a pragmatic function in so far as moral wisdom is concerned. R. Segal (2004) suggests that "Myth functions, first, to reveal the existence of a severed, deeper reality; second, as a vehicle for actually encountering that reality; third, as a model for others." (p. 131) Since art and literature frequently return to their primitive origin, many modern intellectuals believe that literature should be brought closer to myth. According to Northrop Frye (1957): Total literary history moves from the primitive to the sophisticated, and here we glimpse the possibility of seeing literature as a complication of a relatively restricted and simple group of formulas that can be studied in primitive cultures. (p. 19)

The myth of Electra involves the stream of the past into the present. It represents one of the most controversial myths in the history of human civilization. This particular quality of the myth justifies the prevalence of numerous contemporary dramatic interpretations of it. Since the twentieth century has been a battleground for concurrently contradicted ideologies, the Electra theme conveys many intellectual, artistic, and critical views. The theme of the classical myth is well-known: King Agamemnon was murdered by his wife, Clytemnestra, and her lover, Aegisthus, upon his arrival from the Trojan War. After many years of exile, Orestes, son of Agamemnon and Clytemnestra, returns home to avenge his father's murder and rescue his people from the tyrannical rule of the usurper. Electra, whose life is a series of anguish, torment, suffering, alienation, and lamentation, intensifies her brother's enthusiasm to accomplish the horrific double murder; killing his mother and the usurper.

One of the most distinctive dramatic reinterpretations of the Electra myth in the twentieth century is Jean-Paul Sartre's 1943 drama The Flies (Les Mouches). In this particular play, Sartre brings his awareness and artistic integrity to his exploration of the Greek myth in a way that proves his consciousness of the impact of the intellectual climate and the environmental factors on shaping a writer's artistic perspective. Sartre's prime concern is to depict modern human beings' existence within the context of the prevailing intellectual climate. His sensitive awareness of man's position in the modern world and his sincere ethical devotion to humanity have determined his themes. The most distinctive themes with which Sartre is preoccupied are those 
associated with human existence in modern times; tyranny, atrocity, war, rebellion, and oppression. The play shows how Sartre perceives human behaviour in the course of inevitably challenging moral crises. He is aware of the growing sense of isolation, alienation, despair, and estrangement that predominates the increasingly collective modern world and paradoxically "tends to destroy the individual's selfhood." (Corrigan, 1964, p. xvi) The Flies is an embodiment of the dehumanizing implications of the modernist situation and a manifestation of the profound haunting feelings of frustration, futility, and loneliness. The inability to cope with the dehumanizing coexistent moral codes results in a deep feeling of absurdity about human existence. The ultimate purpose of the committed man of letter, in this context, is to "make a new union out of his secession- to make his initial act of revolt the occasion for a new kind of grace" (Burstein, 1964, p. 11).

Accordingly, in approaching the Greek myth, Sartre has neither discarded the cultural context in which he existed nor ignored the socio-political conditions in which his country was involved. The Flies must be considered within the political context in France under the German occupation. It was the existence of an oppressive, alien force that allowed the man of letters to raise the issue of freedom more vigorously than ever before. Sartre's interpretation of the ancient Greek myth illustrates France's political circumstances during the tyrannical, oppressive Nazi occupation. In this particular drama of liberty, Sartre reinterprets the Greek myth from a new perspective. He tries to prove to the reader that "freedom" is not only an "abstract concept, to be admired or ignored, it (is) an unavoidable necessity, part of our every condition of being." (Bradby, 1984, p. 38) Sartre, apparently, "insinuates that Les Mouches intended to convey a clandestine message to the French audience, in which he criticizes the German occupier." (Ghyselinck, 2010, p. 354) Hence, the Flies of the title symbolize the plague of Nazi occupation: "The Flies is an indictment of Nazism, the Vichy regime, and French collaborationism." (McCall, 1969, p. 23) Sartre exposes the temperament of the tyrannical oppression of totalitarian regimes in juxtaposition to the individual freedom that defies it, on the one hand, and the possibility of regime transformation due to rebellion, on the other hand. The association of political regime, represented by Aegisthus' tyrannical rule as a facade of the Nazi occupation within the myth structure in The Flies, promotes the deconstruction of power. The drama becomes a plea for resistance. The Flies can be seen as "much about the creation of fraternity through revolt, the necessary forging of the community by a break with the inertia of shoddy individual soul-searching, as it is about the act of a free individual." (Ryder, 2009, p. 81)

Sartre has made a significant transformation in the Electra myth to adapt it to his philosophical perspective. The Flies "consists of a highly complex content, and this is due to the creative influence of Sartre's existentialist philosophy, which centers around the notion of freedom as a constant necessity." (Ghyselinck, 2010, p. 355) The Flies represents a translation of the Existentialist philosophy in a dramatic form. Hence, one cannot approach the play without venturing into Existentialism. Existentialism is defined in Oxford Dictionary as: "a philosophical theory or approach that emphasizes the individual person's existence as a free and responsible agent determining their own development through acts of the will." The Flies represents an investigation of the different relations of human beings to their actions, whether they try to rid themselves of them, as Electra does after the act of matricide, or completely acknowledge responsibility for them, as in the case of Orestes. In this respect, the protagonist's tragic suffering no longer emerges from a predetermined fate imposed by the gods; on the contrary, it is replaced by an existential tragedy, namely, that of man's commitment to his choices. Accordingly, in Sartre's The Flies, commitment represents the inevitable path to the anticipated existential 
freedom. In Sartre's drama: Acts are no longer considered as products but as inventions. Therefore, an act is seen as a creation, almost unique and irreplaceable. Emphasis is put on the isolation of each individual in his action or his suffering. The isolation of man in action is often symbolized by the choice of the heroes whose basic situations are exceptional. (Guicharnaud, 1975, pp. 134-6)

Orestes' situation is exceptional. His background has made him an isolated stranger from all the citizens of Argos. The shadows of their past do not plague him; accordingly, he has given his existence an essence by committing the free act of matricide. In The Flies, Orestes is in search of an existentialist identity. He is satisfied with the apparent truth that man must be free in his life and his decisions. This character, whose acts and decisions evolve at every moment of the play, profoundly embodies Sartre's Existentialism; he declares himself free. He recognizes that the only way to make his existence meaningful and valuable is to assert his freedom by rebelling against established orders. Sartre intends Orestes, the existential figure, to be a free human being who will never be directed by Zeus's laws. Orestes has the ultimate conviction that no god can dominate a free human being's destiny: I am doomed to have no other law but mine.... For I, Zeus, am a man, and every man must find out his own way. Nature abhors man, and you too, the god of gods, abhor mankind. (Sartre, 1977, p.159)

The gods represent forms of aggression used against human beings to suffocate their human growth, suppress their identity, and convert them into distorted creatures through an alleged sin and sense of guilt. Sartre's preoccupation with the hierarchal structures of power is well illustrated in adding the figure of "Zeus." Commenting on the dramatic role of Zeus in the play, Evans (2008) writes: "The insertion of this figure of absolute power into the action of the play ... points to power dynamics and totalitarian regimes as key concerns of the play." (p.3) Sartre emphasizes that human beings must create their free will and transcend the limitations imposed on their existence by historical and metaphysical forces. Free will can be defined as "a kind of power or ability to make decisions of the sort for which one can be morally responsible." (Fisher, Kane, Pereboom, and Vargas 1) Perhaps their cowardice, passivity, and acceptance of victimization have transformed the people of Argos into puppets in the hands of different shaping forces, forces that cause them to degenerate into blind objects. Sartre believes that only when human beings face tyranny will they regain their dignity and freedom. Accordingly, they will find meaning in their existence and become the masters of the universe. The role of human consciousness, in this respect, is to give life a value, and this ultimate value is freedom: Orestes: You are the king of gods, king of stones and stars, king of the waves of the sea. But you are not the king of man. Zeus: So I am not your king? Who then, made You? Orestes: But you blundered; you should not have made me free. Zeus: I gave you freedom so that you might serve me. Orestes: Perhaps. But now it has turned against its giver. And neither you nor I can undo what has been already done. I am my freedom. No sooner had you created me than I ceased to be yours. (Sartre, 1977, pp.156-157)

Orestes is free, but his freedom depends on isolation. He is outside the blind conformity of collective behaviour; accordingly, he is not essentially a community member and does not believe in the gods. As an enlightened human being, he is free from all superstitious ties. Orestes has a distanced perspective on society; he has always seen himself as alienated, isolated, and removed from others. He has been a separate entity, estranged from other individuals; accordingly, he has never seen himself as "a man among men," as part of humanity. He is lonely in his freedom. Hence, out of his free will, he chooses commitment; he chooses to identify himself with his sister and his people through performing the horrible act of revenge. According 
to Jones (1962), Sartre's heroes are not primarily unhealthy people and, although they have problems that are essentially their own, they can be said to be representatives of twentiethcentury men. They are all aware of their times, and they are usually part of them. They all have objectives, and, bizarre enough in the modern theatre, many of them do accomplish the task which they have set for themselves. Orestes in Les Mouches frees Argos from its remorse. (p. 95) Because Orestes is alienated and free from all entanglements, he seems to be superior to the People in Argos, and, accordingly, he can create his free will through existential choices. His awareness of his superiority enhances his freedom and makes it possible for him to perform an act that, as he anticipates, will emancipate the Argives from the constraints of guilt and remorse. Bradby (1984) suggests that: Orestes is seen to move from an experience of unreal freedom, that is, a mere absence of restraint, to a point where he accepts the restricting limitations of a particular situation, and so achieves great freedom. (p.38)

Locked into a closed, egocentric existence, Orestes has no reason to be involved in the people's hideous existence in Argos. Moreover, upon his arrival, he is greeted by oppressive heat and rude rejection. Orestes has been given all the physical encouragement to leave Argos: Every aspect of Argos exudes putrefaction and disease, from the black-clothed women who spit as they back away from the strangers to the idiot whose puss-oozing eye feeds the flies, from the statue of (Zeus) smeared with blood to the hermetically shuttered houses. Argos is offensive not merely to the eyes, but also to the nose, with its stench of a butcher shop; to the ear, with its horrible cries that echo through the deserted streets; and to the touch, with its merciless sun and stagnant air. (Powell, 1981, p. 146)

Another type of encouragement to leave Argos with a clear conscience is presented by Orestes' Pedagogue, who has accompanied him throughout his voyages and who assures Orestes that he is not committed to the strange inhabitants of this repulsive city. Orestes' relativistic attitude towards moral codes on his assumption that there is no absolute good or evil. Thus, Orestes is free from any moral commitment towards the Argives; accordingly, he can view their adherence to any code of ethics from a distance and scorn it from a superior position of cynicism.

Nevertheless, he chooses commitment instead of isolation. He is now eager to have his memory peopled by human beings. He questions the notions of justice and order that both Zeus and Aegisthus have established, and he is ready to challenge them. This commitment begins to take a potentially real dimension with the appearance of his sister, Electra, who actualizes the idea of revolt against the status quo, the oppressive supernatural and political order, and the alienating forces of society, which Orestes' Pedagogue reinforces. Electra presented for Orestes the notion of commitment illustrated in man's "freedom to," instead of the vain "freedom from." Sartre (1984) believes that "Man is condemned to be free" (p.707). Accordingly, he is "responsible for the world and himself as a way of being." (p.707) Man is also responsible for the acts that contribute to the construction of his existentialistic identity. Man is "no longer anything but a freedom which perfectly reveals itself and whose being resides in this very revelation." (p.701)

Even though Orestes represents a mouthpiece of Sartre's philosophy, as Sartre focuses on his behaviour during and after committing the act of matricide, Electra is by no means subordinate to him. Sartre makes Orestes her double; while he is an outsider who does not belong, she is inside, yet, she is spiritually alienated from her people. This representation method may help the reader view the theme in a new light and perceive Electra as a different version of Orestes. Indeed, Electra belongs to Argos; however, she has an overwhelming feeling of loneliness and isolation. Her inability to act springs from her social context as a woman locked 
up within the confinements of her patriarchal cultural heritage. Paradoxically enough, Orestes, the exile, can accomplish a task for the Argives in an attempt to be an integral part of their existence. Electra, who is physically tied to Argos, experiences a deep sense of alienation and exile, both from society in general and from specific individuals: Clytemnestra, her mother, and Aegisthus, the usurper. These particular individuals seek to increase her distance from the throne and treat her as a slave. However, despite her spiritual alienation, she shows Orestes how to be "responsibly" engaged in the Argives' lives. Electra is crucial to Orestes' decision to remain in Argos and achieve their mutual revenge against Clytemnestra and the Aegisthus. Electra perceives Orestes' only responsible cause of action as a channel for his commitment.

Electra has spent fifteen years in lamentation, and though she is incapable of action, her lamentations have the power of action in the sense that they torture Orestes and provoke him to accomplish the matricide. Electra fiercely hates her mother, Aegisthus, and Zeus, the god who protects them. Since the murder of her father, Agamemnon, she has endured the abhorrently humiliating life of a slave. Nevertheless, while Electra has been undergoing this suffering, she has caused Clytemnestra and Aegisthus to suffer, too. Through her interminable antagonism, she is capable, thereby, of eking out her revenge into bits and pieces. Electra's mourning has the power of action. She believes her ruthless hatred is a substitution for revenge. Locked up within the captivity of her gender role in a male-dominated cultural context, she delays the burden of revenge until the arrival of a patriarchal figure, the savoir, who will end her sufferings. Sartre (1977) illustrates Electra's situation of waiting for Orestes in her own words: He will come; he is bound to come. He is of our stock's, you see, he has crime and tragedy in his blood, as I have- the blood of the house of Atreus. I picture him as a big, strong man, born a fighter, with eyes like our father's, always smouldering with rage. He, too, is doomed; tangled up in his destiny, yes, one day he will come, this city draws him. Nothing can hinder his coming, for it is here he can do the greatest harm and suffer the greatest harm.... I must stay here to direct his rage- for I, anyhow, keep a clear head to point to the guilty and say: "Those are they, Orestes, strike!"(p.114)

Electra is aggravated by fate in the form of her heredity. The Orestes of her dream must be motivated by the same blood concerns and is supposed to bear the same burdens of their environmental conditions. Electra's words reveal a fierce female whose vision is warped by hatred, hatred for the darkness in Argos, hatred for her existence, and hatred for her mother and Aegisthus. She can plant the seeds of Orestes' deed, which, in her existential cowardice, she later repudiates. In The Flies, as in the classical interpretations of the myth, the female character is dependent on the male deliverer. Electra is a powerless dreamer who is spiritually paralyzed and incapable of action. Compared to her brother, the Existentialist protagonist, she represents "the other", in so far as she is not put in an existentialist context as a result of being unable to assume responsibility for an action. Electra is the product of her environment, not her acts, accordingly, she does not triumph over the limitations of the status quo either by acting or by actualizing her goals. Sartre's Electra collapses at the end of the play because of her inability to comprehend the nature of action and commitment. In this respect, she is a descendent of Euripides' Electra.

Nevertheless, through Electra, Orestes is to be initiated into a passionate, responsible, caring, conscious, and meaningful action. Under the influence of Electra, "Orestes would welcome being constrained by a commitment allowing him 'to go somewhere,' to perform an act that would be entirely his own." (Liapis, 2014, p. 131) Though Electra herself lacks the courage and vision required to accomplish a specific action, she brings Orestes face to face with their mother and Aegisthus and confronts him with the results of their tyrannical rule. Only after the accurate knowledge Electra' gives him is that Orestes begins to realize the implications of 
revenge and adheres to the responsibility she thrusts on him. Electra is capable of awakening her brother's new thoughts and emotions; she enables him to see people as human beings and, consequently, realize his humanity by forming an essential connection between himself and others. In Existentialism is a Humanism (2007), Sartre states that "when we say that man is responsible for himself, we do not mean that he is responsible only for his individuality, but that he is responsible for all men." (p. 23) Electra has a significant impact on Orestes' transformation; she makes him aware of the notion of commitment and encourages him to deplore the teachings of his past life. The choice to act, according to Debusscher (1970), "leads Orestes to freedom: instead of remaining in Argos, he leaves the city, for he has conquered a new citizenship, that of MAN, because he has grown conscious of his own freedom." (p. 309) This decision reflects Orestes' potential for responsible human action, which can only be actualized if he remains. Orestes decides to act in order to "create an Orestes who is both self-determining and part of the people." (Powell, 1981, p. 161) Liapis (2014), on the other hand, suggests that: The shaping of one's existence into essence cannot be made by strictly individual standards of truth; the very fact of choosing certain standards implies and presupposes a belief in their universal validity. Thus, to realize oneself means necessarily to realize all others. (p. 138)

Sartre is mainly concerned with human situations to the extent that his characters are not primarily distinguished by psychological traits but by their actions within the context of a particular situation. Guicharnaud (1975) suggests that in Sartre's drama, Physical action, generally violent, takes on a new value in that [his] basic philosophy consists in destroying the importance traditionally accorded to motives. What really counts are not the reasons for an act but the act itself, its present significance, and the significance it gives to the characters and the world. In other words, the search for psychological causality of an act is either shown to be vain or replaced by an investigation of the act's significance. (p. 132)

However, the element of human motivation is not absent from Sartre's interpretation of the Greek myth. In Sartre's Electra, there is room for psychological depth. Her character is not straightforward or obvious; she has a multi-dimensional personality. She does not seek a perfect ideal but preferably adjusts to the motivations of her human situation. Moreover, Orestes' choice of commitment is, ironically, not based upon moral obligation, but on the emotional motivation to achieve a victory over his sense of alienation; it springs from an urgent desire to belong to Electra, to Argos, and even to himself: But who am I, and what have I to surrender? I'm a mere shadow of man... I wonder from city to city, a stranger to all others and to myself, and the cities close again behind me like the waters of a pool. If I leave Argos, what trace of my coming will remain, except the cruel disappointment of your hope... I want my share of memories, my native soil, my place among the men of Argos... I wanted to be a man who belongs to someplace, a man among comrades. (Sartre, 1977, pp.117-118)

Sartre's Orestes stands as a representative of the twentieth-century intellectual man. In The Flies, Orestes strives for accomplishing a meaningful, purposeful action, which would liberate the Argives from the futility and barrenness of vagrant impassiveness. In "The Forgers of Myth", Sartre sums up the characteristics of the Existentialist protagonist: Man is not to be defined as a "reasoning animal," or a "social one," but as a free being who must choose his being when confronted with certain necessities, such as being already committed in a world full of both threatening and favourable factors, among other men, who have made their choices before him, who have decided in advance the meaning of these factors.(p. 123)

Thus, Orestes chooses commitment to human interaction, despite his awareness of the fact that such interaction is the source of despair and a reminder of the gulf from which absurdity is born: 
"There are people who are born committed: they have no choice, they have been thrown on a path, and at the end of that path there is an act that awaits them, their own act." ( 1977,p.139) The Flies "is not only an exhortation about ethical responsibility, but also a performance of the difficulties attendant to that duty." (Ryder, 2009, p. 78) Orestes believes that human contact is the basis for the only form of transcendence. Being rootless, alienated, and isolated, Orestes recognizes that the double act of matricide and tyrannicide can "enable him to appropriate a personhood, an identity similar to the fiction of a righteous, vengeful Orestes that had been haunting Electra for years." (Lapis, 2014, pp. 126-127) Although his choice is emotional, not heroic, the existentialist protagonist assumes full responsibility for his free act of matricide: Orestes: I am free Electra. Freedom has crashed down on me like a thunderbolt. Electra: Free? But I- I don't feel free. And you - can you undo what has been done? Can you prevent our being the murderers of our own mother? Orestes: Do you think I'd wish to prevent it? I have done my deed, Electra, and that deed was good. I shall bear it on my shoulders... the heavier it is to carry, the better pleased I shall be; for that burden is my freedom.(Sartre, 1977,p. 140)

Orestes' perception of the inevitability of a violent action is different from that of Electra. His decision to act looks forward to the future, whereas Electra's looks backward into the past; while Electra's prime concern is avenging Agamemnon's murder, Orestes' ultimate purpose behind accomplishing the horrible deed is to liberate the Argives from the deadly influence of Aegisthus and Clytemnestra. His choice is made intelligently, without guilt, and free of superstition. Orestes, the Existentialist protagonist, appropriates his destiny; he is free to establish his hierarchy of moral values in which the destruction of tyranny and the reaffirmation of human dignity are superior to political and religious dictates. He does not just declare he is free, but he forces Zeus to confess that the gods are powerless to stop him and end his freedom. Having begun life with the illusion of disengagement, Orestes, at the cost of a great struggle and a double murder, succeeds in creating the 'royal way' that leads him to assume responsibility for his acts. Orestes has to avoid the human and divine traps that transform man into an instrumental object. By murdering his mother and Aegisthus, Orestes realizes that the act is his and only his, and he alone bears the burden of responsibility. He rejects imposing the responsibility on outside forces, whether human or metaphysical.

In The Flies, the gods are no longer capable of compelling the existentialistic hero to act, as they do in Aeschylus's drama; accordingly, the action becomes the human being's conscious choice. Evans (2008) observes that "Orestes' independence threatens to undermine the unity of the totalizing myth and destabilize the fixed focus of the Argives upon which [Zeus'] authority depends." (p. 4) In The Flies, Sartre denounces religious codes and reveals the effect of external forces on the individuals. If a man is free from metaphysical forces, he is responsible for shaping his destiny: Orestes: Why should I feel remorse? I am only doing what is right. Aegisthus: What is right is the will of god. You were hidden here and you heard the words of Zeus. Orestes: What do I care for Zeus? Justice is a matter between men, and I need no god to teach me it. (1977, p. 137) The tyrannical oppressors, Aegisthus and Zeus, collaborate to blind the citizens of Argos to their freedom. Aegisthus: I have no secret. Zeus: You have. The same as mine. The pain of gods and kings. The bitterness of knowing men are free. Yes Aegisthus, they are free. But your subjects do not know it, and you do. Aegisthus: Why, yes. If they knew it, they'd send my place up in flames. For fifteen years, I've been playing a part to mask their power from them. Zeus: You see, we are alike. (Sartre, 1977, p.134) Zeus and Aegisthus organize the collective spectacle of men and the universe in the play. The gods' conception of order is based on the assumption that a paralyzed citizenry is an ordered citizenry; accordingly, humanity must be totally and 
unconditionally subordinate to the divine rule. They are aware of the influence of the metaphysical forces and the oppressive political systems that utilize religion to dominate people. Therefore, they control the people of Argos by deepening their sense of guilt and remorse. Through the agency of Aegisthus, who represents an influential instrument for sustaining Zeus's power, Zeus controls the lives of his subjects through fear. Fear of both the gods' worth and the "dead" has dehumanized the Argives and transformed them into living corpses. Under complete domination and supremacy, the people of Argos have experienced a degrading state of oppression and psychological objectification.

The exertion of power is an essential aspect of objectification because it intimidates the target to be objectified, forcing the victim to surrender in utter submission. It occurs either through blackmailing the target of objectification, the people of Argos, or through the objectifier's constant reminders of the darkest memories from which the objectified might be trying to escape. The objectifier, Aegisthus, recognizes that the points of weakness in his objectified prey, the people of Argos, are fear and guilt. Since Agamemnon's death, the people of Argos have been living in terror, dread, and repentance by the will of Aegisthus, who has invented a yearly ritual of the dead to sustain his control over them. On the "Day of the Dead," the dead avenge themselves against those who injured them in life. The Argives' guilt can never be expiated, and accordingly, they have to live in remorse. Remorse is an essential element in destroying human beings' ability to look ahead and think of the possibility of the existence of a better life. Aegisthus and Clytemnestra have injured every citizen with their rule of remorse and repentance.

In his drama, Sartre exposes the destructive, dehumanizing fear that has been instilled in the Argives and intensified by superstition. This fear is exemplified by the image of "the dead eyes" of the people who are blinded by superstition. Zeus and Aegisthus uphold their power by "controlling the vision of [their] subjects, by having a single focus upon which their sights are fixed." (Evans, 2008, p. 4) The people's terror reaches its climax during the ritual calling forth of the dead from the underworld. During this ritual, the dead are invoked through anger, bitterness, and rage to rise and make the Argives repent. In The Flies, "the living do not remember the deceased who perished gloriously, but instead devote themselves to the memory of those whose lives and deaths were atrocious." (Ruffy, 2017, p. 17) Under such dehumanizing conditions, the citizens of Argos view life as their greatest sin, and they are compelled to atone for their crime of being alive by leading a death-in-life existence. As an existentialist protagonist, Orestes can reject Zeus' menacing threats and the Argives' puerile ethics and omnipresent guilt culture. He rebels against the "abusive usurping power, which keeps alive the memory of the dead and the recollection of a terrifying past." (p. 58) Unlike the citizens of Argos, he is not haunted by memories of guilt and remorse, and accordingly, he is the only one capable of action. Electra, on the other hand, is striving to rebel against this reprehensible condition. Her rebellion is manifested in the sharp contrast between her stunning white dress and the black-clothed crowd. At first, she draws forth angry comments from the crowd, but her words and joy slowly bend them. Electra struggles to transcend the status quo and destroy the present state of affairs by projecting a vision of a different kind of life in which people attain purification in birth rather than in death. In this respect, Electra assumes the responsibility of creating a better world out of the morally vicious one.

Nevertheless, this attempt fails because Electra's potential for responsible action to reform the Argives' sub-human life, is destroyed by Aegisthus' tyrannical authority, which is enforced and supported by the supernatural power of Zeus. Aegisthus uses fear to maintain order 
among his subjects, who have permitted themselves to be enslaved by his rule of repentance, remorse, and fear. This order represents a manipulative force by which Aegisthus and his immortal counterpart, Zeus, strive to defend their self-interest; they blind human beings to the possibility of the existence of any other way of life. Aegisthus is a king of tyranny in that he represents the oppressive external order that deprives his subjects of their fundamental human dignity. Electra's attempt collapses due to the interference of superstition, fear, guilt, and her lack of a heroic adherence to responsibility.

The Argives are ready to abandon the hope of salvation and accept Aegisthus' dehumanizing treatment in exchange for his absolving them of all responsibility for their words and thoughts. They, thereby, choose a life of blindness, remorse, and non-responsibility. As a result of accepting to be ruled by Aegisthus' notion of order, they cannot achieve a permanent transformation from an attitude of non-responsibility to one of responsibility. On the other hand, Orestes is not a salve of this notion of order; he is not dominated by any religious or social doctrines. Sartre believes that man is free to accept or reject any given moral order. Orestes, in his freedom, is not caged in this divinely ordered universe; accordingly, he must "bear the anguish of full responsibility for inventing values by his acts." (McCall, 1969, p.12) In The Flies, Sartre presents an antithetical view to the assumption that the human being is an integral part of the universe's highly complex structure. Sartre views the human being as separated from nature by his/her freedom. Orestes' act of murdering the tyrant is intended to free the oppressed people who have been misled by a haunting sense of guilt and crime. It is Orestes' awareness of his freedom that makes him superior even to the gods themselves. Aegisthus communicates to Zeus the fear of the collapse of his political authority due to Orestes' awareness of his freedom: Does he know he is free? Then, to lay hands on him, to put him in irons, is not enough. A free man in a city acts like a plague-spot. He will infect my whole kingdom and bring my work to nothing. (Sartre, 1977, pp. 135-136)

Being a detached outsider, Orestes is aware of his capacity to act; therefore, he is qualified to destroy the notion of an externally imposed order. Indeed, Zeus has formed the universe, but by mistake, he has made man free. Only man can either accept or reject a particular status of existence, and even the gods themselves are impotent in front of man's freedom. Orestes' freedom from the constraints of order is developed into a freedom to establish his own moral codes and to assume responsibility for his actions. Being free, Orestes represents the savoir who strives to lead his people towards self-knowledge and salvation. Ironically, Orestes' attempt at purifying the people of Argos from guilt, remorse, and oppression is conceived by Aegisthus as contamination that will result in pollution in so far as it challenges the moral code he has established with the help of the divine power of Zeus. Thus, both Electra, who has spent her life dreaming of the deed, and the people of Argos, whom Orestes struggles to save from mental and emotional slavery, revile him. Orestes:The folk of Argos is my folk. I must open their eyes.Zeus: Poor people! Your gift to them will be a sad one; of loneliness and shame. You will tear from their eyes the veils I had laid on them, and they will see their lives as they are, foul and futile, a barren boon. (Sartre, 1977, p.160)

After committing the act of matricide, Orestes becomes a figurative exile, and now he is even more alienated from Electra than ever before. Nevertheless, even though his departure is not heroic, as will be elucidated later, Orestes symbolically restores human dignity when he leaves, taking the flies with him. The city is in the process of purification as a result of the free commitment of one man. Orestes takes upon himself the crimes of the city and the repentance of its citizens: Orestes realizes that his new state is one of exile, and he is proud of it because, by 
choosing it himself, he has discharged the obligations to his people. Although he is now technically a part of Argos, [Orestes] refuses the throne, saying that he wishes to be a king without a country and without subjects. (Jones, 1962, p. 98)

If he remains in Argos as a king, Orestes will be contradicting the high positive value presented in The Flies; the value of freedom. Becoming a king implies imposing an external order on others' freedom by judging their actions, the actions for which only they can assume responsibility. Thus, Orestes prefers to depart carrying the burden of his freedom, responsibility, and determination to create his essence, which exiles him from Electra and the people of Argos. Even though he is harassed by the Erinnyes -the flies-, and threatened with stoning by the Argives, he remains fixed in his remorseless commitment. The play ends with Orestes standing utterly alone in a bright light before the Argives, who are now trying to open their "dead eyes" to the light of freedom; he then leaves Argos, followed by the Erinnyes.

The flies represent the unbearable burden that Orestes has inflicted upon himself. They represent a "sumptuous metaphor intended to show men that responsibility is not synonymous with guilt." (Guicharnaud, 1975, p. 138) Orestes leaves hounded by the implications of his action. The flies represent both Greek Furies and the outward visible signs of collective guilt and remorse which plague the city. By the end of the drama, Orestes leads them out of Argos. Since Orestes does not feel guilty and courageously acknowledges responsibility for his action, the flies may pursue him, but they can never cause him remorse. The Furies, as embodied by the flies, necessarily follow Orestes as a natural development of the classical material, but under the "constraints of the Sartrean transformation, these furies have no power over him in terms of the meaning attributed to them." (Cech, 1984, p. 441) The departure of the flies symbolizes the "deliverance brought about by Orestes' act in spite of Argos." (Maurois, 1967, p. 317) Orestes intended his actions to result in spiritual salvation, despite his isolation and exile. The flies represent Orestes' burden in being an exile and alien in the world where he must make his lonely way. This burden is immense given that human beings' fundamental nature cries out for attachment.

The paradox of the play's ending lies in the fact that throughout the drama, the philosophical debate between Orestes and Zeus has developed a notion that remorse is not an externally-imposed condition; on the contrary, it is willed. Subjugation, in this context, is a choice. In this respect, the remorse felt by the people of Argos can only be expiated by them. Thus, Orestes' assumption of the flies and his act of liberating the citizens of Argos can be viewed, in this context, as illogical, for no one can take the sense of guilt from others. Taking the flies away, in this respect, is not heroic. To highlight the illusion of freedom in The Flies, Sartre dramatizes a process where a latent reality supersedes the false expectation. Electra's ultimate dream is the return of Orestes, the saviour, who will deliver his people, punish the usurper, and reclaim his rightful position by destroying the status quo. Nevertheless, the hero's arrival results in the violation of Electra's dream, as it leads her away from the past down an unpredictable future. So long as Orestes is unrecognized, Electra is awaiting him in helpless segregation. Her predicaments, emotions, and expectations are directed towards the absent avenger: "But someday he will come, the man I'm waiting for, carrying a long, keen sword.... Then he will draw his sword and chop you in two." (Sartre, 1977, p. 83)

Electra is dominated by an exaggerated yearning for revenge and restoration. She believes that violence is the only means to achieve justice and correct the wrongs done to her: "an evil thing is conquered only by another evil thing, and only violence can save them." (Sartre, 1977, p.113) She views the need for revenge from the perspective of the current situation; her 
father is murdered, the usurper is ruling the city, her mother is living with the murderer, her brother is an exile, and she is treated like a slave. These circumstances cannot be taken for granted if she and her brother correct the wrong, which deepens her feeling of injustice and makes giving up vengeance an abnormal act. Nevertheless, Orestes' actual presence frustrates her dreams; when she discovers that he is not the transcendent rescuer, she wishes he had never come.

Because Orestes has a noble heart, Electra concludes that he is not the man she has been waiting for fifteen years: "I could never lay such a load upon a heart like yours; a heart that has no hatred in it." (Sartre, 1977, p.116) When Orestes, under Electra's pressure and his own urgent psychological need for belonging, agrees to perform the act of revenge and matricide, brother and sister have become inseparably associated in the false anticipation of what their union means for them. Deliverance, revenge, dreams of restoration, and expected happiness turn into ruin, desolation, and exile: "Having accepted the crushing burden of free choice, Sartre's Orestes leaves Argos to go into exile." (Liapis, 2014, p.152) While approaching the matricide, Electra seems to be controlled by peculiar violence and intensive hatred: "We shall never rest again until they both are lying on their backs, with faces like crushed mulberries. In a pool of blood." (Sartre, 1977, p. 123) Nevertheless, the mercilessness which blinds her to the meaning of revenge, until the cruel reality of the matricide emerges, gives way to feelings of guilt, remorse, and emotional breakdown: You frighten me. I had a dream. I saw our mother lying on her back. Blood was pouring from her, rushing under the doors. A dream.... Feel my hands. They are icy. No, don't. Don't touch me. Did she really bleed so much? (Sartre, 1977, pp.146)

Electra is a dreamer who is incapable of action, and when the desired action is accomplished, she repudiates Orestes because he has deprived her of her very reason for existence; her dream of revenge, which has always been nothing but a dream: Zeus: Come now! Surely you can trust my word. Do I not read in men's hearts? Electra: And you read in mine that I never really desired that crime, though for fifteen years I dreamt of murder and revenge? Zeus: Boh! I know you nursed blood-thirsty dreams- but there was a sort of innocence about them. They made you forget your servitude; they healed your wounded pride. But you never really thought of making them true. (Sartre, 1977, pp.153)

In Act III, after the matricide, Electra and Orestes are refugees in Apollo's temple. The Flies-become-Erinnyes awaken Electra as they externalize her thoughts, fear, and defensive remorse. Incited by remorse, in the forms of the Erinnyes, Electra denies any responsibility for the murder, and she repeatedly asserts that the act belongs to Orestes. Electra physically gives herself to the remorse personified by the Erinnyes. Her penitence springs from her inability to recognize the crime as her own and come to terms with it. Over the years, she has been enslaved by hatred. She believes that the destruction of her mother and Aegisthus was the highest possible good. Her desire for revenge has been an intensified passion, and she has never questioned its rationality. When this desire is actualized, she refuses to admit her responsibility for the murder of Clytemnestra and Aegisthus. As he has blinded the Argives to the truth of their freedom through remorse, Zeus helps Electra disguise her responsibility for her thoughts. She resigns her freedom to choose what is morally right in favour of an externally-imposed system of rules directed by a tyrannical, supernatural power. Zeus says: You are a little girl, Electra. A mere child. Most little girls dream of becoming the richest or the loveliest woman on earth. You dreamt of becoming the saddest, most criminal of women. You never willed your own misfortune. At an age when most children are playing with their dolls, you, poor child, who had 
no dolls, who had no friends or toys, you toyed with dreams of murder, because that is a game to play. (Sartre, 1977, pp.153)

Electra fails to adhere to the existentialist principle that the value of existence is built on the commitment to a particular action and the courage to acknowledge responsibility for it. After the deed is done, Electra, in contradistinction to Orestes, denies any commitment to it and throws the entire responsibility on her brother's shoulders: Electra:Let me look at you. You killed them. It was you who killed them. You are here beside me, you have just walked up, there is nothing written on your face, no brand... And yet, you killed them. Orestes: Why, yes. I killed them. You, too, make me afraid. Yesterday, you were so beautiful. And now you look as if some wild beast had clawed your face. Electra: No beast. Your crime. It's tearing off my cheeks and eyelids; I feel as if my eyes and teeth were naked. Orestes: Electra, we planned this crime together and should bear its brunt together. Electra:You dare say I planned it with you?... I dreamt of the crime, but you carried it out, you murdered your own mother. (Sartre, 1977, pp. 1468)

Instead of achieving triumph through the act of vengeance, Electra gains only guilt and remorse. Being incapable of facing the consequences of the act of matricide, she is denied any heroic stature. She does not possess the courage of her convictions; accordingly, she deviates from the classical Electra figure, except for Euripides's Electra, who, under the influence of guilt and remorse, breaks down. Faced by the Furies, Electra plugs into remorse and denounces the deed. Sartre's Electra illustrates the shift in our attitude towards the heroic in tragedy; she cannot accomplish a tragic heroine's role. While she shares her Greek counterparts' deep antagonism, she fails to share the quality that redeems and humanizes them in the face of their intense antagonism; she lacks the capacity for commitment and embodies weakness and fragility. This weakness is fatal to her revolt and is illustrated in her fear of solitude. Sartre's Electra experiences an irresistible feeling of guilt and remorse. She cannot claim responsibility for an act because of her lack of freedom within the circle of her situation. Being a woman in a maledominated culture, Electra has never been fully conscious of her freedom to choose her actions or judgments because they remain contaminated by fear. Her pursuit of justice and retribution is ultimately undermined because it is compelled by a blind desire for revenge and suffocated by fear. She collapses due to her lack of a wholehearted commitment to a positive value: the achievement of freedom.

If Electra does not conform to the existentialist principle of freedom and commitment, does Orestes conform? It can be inferred that Orestes is not ultimately free, and his insistence on stressing the idea that he is free is, ironically, a mask he wears to hide his human weakness and lack of security. Indeed he has approached the act of matricide guiltlessly, yet, after the deed is, Orestes is not altogether free from the sense of guilt; he is haunted by the image of his dead mother, which is not only illustrated in Electra's face but also the Furies. Orestes expresses his feeling of remorse to Electra in the following words: Do you imagine that my mother's cries will ever cease ringing in my ears? Or that my eyes will ever cease to see her great sad eyes, lakes of lambent darkness in the pallor of her face? And the anguish that consumes you- Do you think it will ever cease ravaging my heart? But what matter? I'm free- Beyond anguish, beyond remorse. (Sartre, 1977, p.149)

Hence, man's capacity to act out of his free will and the possibility of the existence of a deliberative moral choice can be doubted in the light of the psychological and sociological causes and effects. We believe we have free will when we view ourselves as agents capable of influencing the world in various ways. We reason and deliberate among them and choose. We feel it is "up to us" what to choose and how we act; and this means we could have chosen or 
acted otherwise. This "up-to-us-ness" also suggests that the ultimate sources of our actions lie in us and not outside us in factors beyond our control. (Fischer et al., 2007. P. 5)

If the Greeks believe that man's free will is defeated by destiny and intangible factors, modern man's freedom is suppressed through the social forces that make him incapable of action. The problematical issue of free will may be solved if we can "reconcile our intuitive sense of free will with the idea that our choices and actions may be causally determined by impersonal forces over which we have no ultimate control." (Caruso, 2013, p. 2) In his "Preface to A Man For All Seasons," R. Bolt (1990) illustrates the idea that man is not ultimately free due to the restrictions imposed by social order: The individual who tries to plot his position by reference to our society finds no fixed points, but only the vaunted absence of them; "Freedom" and "Opportunity"; freedom for what, opportunity to do what, is nowhere indicated.... In other words, we are thrown back by our society upon ourselves, which of course, sends us flying back to society with all the force of rebound. (p.11)

Moreover, Sartre's subordination of the moral quest for justice to the personal quest for individual authenticity, in a world where human beings are free and conscious of their freedom, relativizes the issue of justice. Based on the assumption that if human beings are ultimately free to determine where justice lies, according to their perception, justice is not an externally imposed order. The conception of freedom and the assumption of commitment to oneself and to one's fellow men, which represents the highest positive moral value in The Flies, contradicts Sartre's conception of justice in its essential nature. The individualistic conception of justice, in this context, destroys the sense of community and, accordingly, that of commitment and responsibility. Orestes, in this respect, may be regarded as an "aesthetic individual, even when with others, [he] remains alone." (Harries, 2010, p.79) The hero is lost, disoriented, and no reference point interests him. Sartre's Orestes has "delivered the Argives to a freedom which they do not want," and his self-imposed exile is the expression of "the bad faith of a democracy that cannot take responsibility for its own freedom." (Leonard, 2005, p.219)

In conclusion, through adopting an interdisciplinary analytical approach, the current study has explored the relationship between freedom and commitment in Sartre's The Flies from the lenses of the Existentialist philosophy and investigated Orestes' perpetual search for an Existentialist identity. The study has traced how the protagonist strives to adhere to the Sartrean principle that human beings are born free; accordingly, they can only attain their destiny in the consciousness of this freedom. The study has shown that through adopting classical antiquity in The Flies, Sartre depicts human beings' relationship to their acts; particularly, the acts that grant significance to their existence. Hence, he converts the Greek conception of destiny into the Existentialist inevitability of the Free Will that would enable his Existentialist hero, Orestes, to transcend the limitations imposed on his existence by political and metaphysical forces. Nevertheless, a critical analysis of the play has proven that human beings are not entirely free; they are not causa sui. On the contrary, they are prisoners in their social constraints and psychological motivations, which prevent them from achieving deliverance and intensify their feelings of despair and spiritual exile. Therefore, Orestes' commitment is, ironically, antithetical to his freedom.

Moreover, the research has highlighted that Orestes' choice of commitment can be regarded as a spiritual death in the sense that the free Orestes is substituted by a persona that submissively accepts the identity assigned to him by others. It has presented Orestes' struggle to create his free will as an Existentialist hero and the burden of commitment that leads to his eternal exile and proves that he is no longer free. The contradiction of Sartre's Existentialism is 
brought to light when he tries to dramatize his philosophy; Sartre has tried to create a free and simultaneously committed existentialist hero; however, the anticipated heroism is undermined by Orestes' emotional need to belong. The researcher has concluded that assuming commitment to others indicates that human beings are not alienated philosophical phenomena; accordingly, Sartre's assumption that human freedom is based on engagement and commitment is, ultimately, paradoxical.

Finally, it is hoped that this study will contribute to the current areas of research in dramatic literature and explicate the rationale behind implementing philosophical perspectives into literary contexts. Further research is needed to examine the reciprocities among literature, philosophy, and mythology. However, it is worthwhile to investigate, with meticulous care, the efficiency of integrating these three domains. 


\section{References}

Aspley, K., Bellos, D., \&Sharratt, P. (Eds.). (1982). Myth and legend in French literature:essays in honour of AJ Steele. Modern Humanities Research Association.

Bolt, R. (1990). A man for all seasons: a play in two acts. Vintage.

Bradby, D. (1984). Modern French drama 1940-1990. CUP.

Burstein, R. (1964). The Theatre of Revolt: An Approach to the Modern Drama. Little Brown\&Co.

Caruso, G. (2013). Introduction: Exploring the illusion of free will and moral responsibility.

Corrigan, R. W. (1964). The modern theatre. Macmillan Publishing Co. INC

Cech, L. M. (1984). Becoming a heroine: a study of the electra theme.

Debusscher, G. (1970). Modern Masks of Orestes: The Flies and The Prodigal. Modern Drama, 12(3), 308-318.

Fischer, J. M., Kane, R., Pereboom, D., \& Vargas, M. (2007). Four views on free will. Blackwell Publishing LTD.

Frye, N. (1957). Anatomy of Criticism: Four Essays. 1957. Princeton: Princeton UP.

Gardner, S. (2009). Sartre's' being and nothingness': A reader's guide. London and New York.

Ghyselinck, Z. (2010) Jean-Paul Sartre's Les Mouches (1943).A Classical Tragedy Revised as a Pièce de Résistance? EVPHROSYNE, 38, 353-365.

Guicharnaud, J. (1975). Modern French Theatre from Giraudoux to Genet. Yale UP.

Harries, K. (2010). Between Nihilism and Faith: A Commentary on Either/Or (Vol. 21).

Kierkegaard Studies Monograph Series.

Jones, R. E. (1962). The Alienated Hero in Modern French Drama. The University of

Georgia Press.

Leonard, M. (2005). Athens in Paris: Ancient Greece and the Political in Post-War French

Thought. Oxford.

Liapis, V. (2014). Orestes and Nothingness: Yiannis Ritsos' Orestes, Greek Tragedy, and

Existentialism. International journal of the classical tradition, 21(2), 121-158.

Malinowski, B. (1971). Myth in primitive psychology. Connecticut.

Maurois, A. (1967). From Proust to Camus: profiles of modern French writers. trans. Carl

Morse. Weidenfeld\& Nicolson: Doubleday.

McCall, D. (1969).The Theatre of Jean-Paul Sartre. New York and London.

Powell, B. J. (1981). The metaphysical quality of the tragic. a study

of sophocles'" electra," giraudoux'" electre" and sartre's" les mouches"(jean giraudoux, jean-paul sartre, greece, france).

Ryder, A. (2009). Sartre's Theater of Resistance: Les Mouches and The Deadlock of Collective Responsibility.

Ruffy, M. V. (2017). Emerging from the oppressive shadow of myth: orestes in sartre, ritsos, and aeschylus. Journal of the Society of Greek Studies,3

Sartre, J. P. (1984). Being and Nothingness. (Hazel E. Barns, Trans) Pocket Books, 1984 (2007). Existentialism is a Humanism..(C. Macomber, Trans).(2001). Jean-Paul Sartre: Basic Writings. Routledge. (1977). The Flies (Les Mouches). (Stuart Gilbert, Trans). Alfred and Kmoph.

Segal, R. A. (2004). Myth: a Very Short Introduction. Oxford University Press.

Susen, S., \&Baert, P. (2017). Reflections on Patrick Baert'sThe existentialist moment: The rise of Sartre as a public intellectual. In The Sociology of Intellectuals (pp. 1-122). Palgrave Macmillan, Cham.

Evans Smith, M. (2008). Myth and Power Structures in Sartre's Les Mouches and La Putain 
respectueuse. CLCWeb: Comparative Literature and Culture, Vol.10 (3), 8. 